\title{
Integrating ethnobiological knowledge into biodiversity conservation in the Eastern Himalayas
}

\author{
Alexander R. O'Neill ${ }^{1,2}$, Hemant K. Badola ${ }^{2}$, Pitamber P. Dhyani ${ }^{3}$ and Santosh K. Rana ${ }^{4 *}$
}

\begin{abstract}
Biocultural knowledge provides valuable insight into ecological processes, and can guide conservation practitioners in local contexts. In many regions, however, such knowledge is underutilized due to its often-fragmented record in disparate sources. In this article, we review and apply ethnobiological knowledge to biodiversity conservation in the Eastern Himalayas. Using Sikkim, India as a case study, we: (i) traced the history and trends of ethnobiological documentation; (ii) identified priority species and habitat types; and, (iii) analyzed within and among community differences pertaining to species use and management. Our results revealed that Sikkim is a biocultural hotspot, where six ethnic communities and 1128 species engage in biocultural relationships. Since the mid-1800s, the number of ethnobiological publications from Sikkim has exponentially increased; however, our results also indicate that much of this knowledge is both unwritten and partitioned within an aging, gendered, and caste or ethnic group-specific stratum of society. Reviewed species were primarily wild or wild cultivated, native to subtropical and temperate forests, and pend IUCN Red List of Threatened Species assessment. Our results demonstrate the value of engaging local knowledge holders as active participants in conservation, and suggest the need for further ethnobiological research in the Eastern Himalayas. Our interdisciplinary approach, which included rank indices and geospatial modelling, can help integrate diverse datasets into evidence-based policy.
\end{abstract}

Keywords: Biocultural diversity, Ethnobotany, Local ecological knowledge, Traditional knowledge, Sikkim, India

\section{Background}

Conservation practitioners have historically considered the role of human communities only or primarily in terms of the threats that extractive and transformative activities pose on the environment [1-3]. As a theoretical consequence, people-free or 'fortress conservation' strategies have become the dominant means of protecting 'natural' systems from anthropogenic influence $[4,5]$. However, over the past two decades, a paradigm shift among conservationists has challenged this convention [6-8]. Termed biocultural approaches to conservation [9], recent programs have integrated the innovations, practices, and worldviews of Indigenous and local communities into policies addressing the rapid attrition of Earth's biological and cultural diversity, hereafter termed biocultural diversity [9-12].

\footnotetext{
*Correspondence: rana.1.santosh@gmail.com

${ }^{4}$ Central Department of Botany, Plant Systematics and Biodiversity, Tribhuvan University, Kirtipur, Kathmandu 44618, Nepal

Full list of author information is available at the end of the article
}

Thematically, biocultural approaches to conservation emphasize the dynamic, multi-scalar feedback loops that link social and ecological processes [9]. They synthesize biodiversity science and ethnographic fieldwork to discern processes that shape extant Earth systems [13]. In doing so, they help deconstruct the dualism separating 'nature' from society, and place local people back in parks as conservation agents [14-16]. Worldwide, such projects have had a variety of reported successes, including heightened spiritual connection and increased environmental literacy $[16,17]$. However, debates continue as to the verity of reported claims and the extent to which conservation programs should serve human welfare [9].

'Landscape' initiatives in the Eastern Himalayas evidence the successful utilization of biocultural principles for conservation purposes [18]. In 1997, an International Centre for Integrated Mountain Development (ICIMOD)-led collective petitioned for the designation of Mt. Khangchendzonga as a dynamic complex of 
socio-ecological interaction $[19,20]$-a biocultural hotspot. The transboundary Khangchendzonga Landscape (KL) is situated within the Himalayan Biodiversity Hotspot [21, 22], and includes Bhutan, India, and Nepal. It incorporates 7.2-million people belonging to diverse ethnic communities, including Indigenous groups like the Lepchas of Sikkim and Darjeeling, the Lhop (Doya) of Amu Mo Chhu Valley, and Walungpas of Walangchung Gola of Taplejung [22]. Because of this complexity, biocultural approaches to conservation facilitated environmental management in the KL. Co-management, communitybased conservation, and integrated conservation and development, for example, have empowered Indigenous and local peoples through non-government organizations (NGOs), and promoted international cooperation along sensitive geopolitical boundaries [21-24].

Since its original delineation, the India-led Khangchendzonga Landscape Conservation and Development Initiative and Feasibility Assessment has committed $14,061 \mathrm{~km}^{2}$ of land, with a population of $6,325,457$ people, into KL conservation policies [25]. KL-India's network is comprised of 16 protected areas (PAs), including a biosphere reserve $(n=1)$, national parks $(n=$ $4)$, and national wildlife sanctuaries $(n=11)$. Within the Indian landscape, the Government of Sikkim's (GoS) efforts in the Khangchendzonga Biosphere Reserve (KBR) are perhaps the greatest testament to claims regarding efficacy of biocultural principles for achieving local and international conservation objectives. Sikkim occupies a $7096-\mathrm{km}^{2}$ zone of the Indian Eastern Himalayas, and has $37 \%$ of its total area, excluding transition zones of the KBR, designated for conservation purposes. The Khangchendzonga National Park (KNP) encompasses over $80 \%$ of all protected lands in Sikkim (Table 1); six additional sanctuaries can be found within the borders of these PAs [25]. For maintaining tribal sanctity and for cultural conservation purposes, the GoS demarcated Dzongu Territory for the exclusive use of the Indigenous Lepcha people [26]. On 17 July 2016, the KNP was inscribed India's first mixed-criteria UNESCO World Heritage Site based on the region's biocultural heritage.

Traditional and community knowledge buttresses conservation policies in Sikkim and is heralded for its adaptive capacity. However, at the same time, Sikkim's biocultural heritage is threatened by 'modernizing' forces associated with globalization and rapid climatic change. As noted in the Sikkim Biodiversity Action Plan, the state lacks formalized and collated records of its biodiversity, which extends into ethnobiological documentation [27]. Even among existing studies, including ethnobiological datasets, records are strictly qualitative, and exist as repetitive, fragmentary notes that lack a consolidated attempt for strengthening policy $[28,29]$. Mobilizing this knowledge and associated datasets into environmental management programs remains a challenge.

In this review, we explore the application of ethnobiological knowledge for biodiversity conservation in Sikkim. Specifically, we ask: (i) What is the spatio-temporal pattern of ethnobiological knowledge documentation?; (ii) How is ethnobiological knowledge partitioned within and among ethnic communities?; (iii) What species are priority targets for conservation, and are these species found within protected areas? In asking these questions, we hope to reframe discourses that focus on the Eastern Himalayas as only or primarily a reservoir of biological and genetic diversity. To our knowledge, our manuscript serves as the first ethnobiological review of the Sikkim Eastern Himalayas.

\section{Methods}

\section{The Sikkim Eastern Himalayas}

Sikkim is divided into four districts, and situated between Bhutan, Nepal, the Tibetan Autonomous Region of China (TARC), and the Indian State of West Bengal. In the 17th Century, Lepcha and Bhutia communities established Sikkim as a Buddhist monarchy under kings termed Chogyals. Chogyals ruled for approximately 350 years until

Table 1 Protected areas (PAs) in the Sikkim Eastern Himalayas, and the potential number of species with ethnobiological records found in each based on reviewed altitudinal range data

\begin{tabular}{|c|c|c|c|c|c|c|c|}
\hline Map ID & Protected Area & Year Established & $\begin{array}{l}\text { District(s) } \\
\text { Covered }\end{array}$ & Area $\left(\mathrm{km}^{2}\right)$ & $\begin{array}{l}\text { IUCN } \\
\text { Category }\end{array}$ & Altitudinal Range (m) & $\begin{array}{l}\text { Estimated Species with } \\
\text { Ethnobiological Records }\end{array}$ \\
\hline 1 & Khangchendzonga National Park & 2007 & North, West & 1784 & IV & $1400-8598$ & 920 \\
\hline 2 & Shingba Rhododendron Sanctuary & 1992 & North & 43 & IV & $3048-4575$ & 280 \\
\hline 3 & Maenam Wildlife Sanctuary & 1987 & South & 35.34 & IV & $2000-3263$ & 609 \\
\hline 4 & Fambonglho Wildlife Sanctuary & 1984 & East & 51.76 & IV & $1524-2749$ & 848 \\
\hline 5 & Kyongnosla Alpine Sanctuary & 1992 & East & 31 & IV & $3292-4116$ & 223 \\
\hline 6 & Barsey Rhododendron Sanctuary & 1996 & West & 104 & IV & 2110-4100 & 560 \\
\hline 7 & Kitam Bird Sanctuary & 2005 & East & 6 & - & $320-875$ & 635 \\
\hline 8 & Pangolakha Wildlife Sanctuary & 2000 & East & 128 & IV & $1760-4390$ & 759 \\
\hline
\end{tabular}

Reference Fig. 3 for geographical location of detailed PAs 
multi-directional process of change resulted in Sikkim's protectorate status and eventual integration into India as its 22nd state in 1975 [30]. Prior to integration, major socioecological changes followed contact with the British East India Company in the mid-1880s. During this period, Nepali migration, here a generic term that includes many castes and ethnicities, was incentivized to promote colonial agricultural development in the Eastern Himalayas [31]. These progressive changes resulted in a rich admixture of ethnobiological traditions from the Greater Himalayas.

Demographic records from Sikkim have varied in quality since the first census in 1891; notwithstanding, Sikkim's population appears to have increased from 30,458 to 607,688 people between 1891 and 2011 [32, 33]. The Anthropological Survey of India identified 25 ethnic communities in the state during its first ethnographic survey between 1988 and 1990 [34]. These communities are generally grouped as: (i) Bhutias (Lhopos, including Denjongpas, Lachenpas, and Lachungpas) and Lepchas, the autochthons of Sikkim who represent less than $20 \%$ of the total population; (ii) People of Nepalese origin, mainly Limbus and Rais, who began migrating to Sikkim from the 1870s and represent more than $75 \%$ of the population; and, (iii) People from the plains of India, including Bengalis, Biharis, and Marwaris [35]. In June 1978, Lepcha, Bhutia, Chumbipa, Dopthapa, Drokpa, Kagate, Sherpa, Tibetan, Tromopa, and Yolmo communities were recognized as Scheduled Tribes in Sikkim; the Kami, Damai, Lobar, Majhi and Sarki were classified as Scheduled Castes. The Government of India considers some 'Nepali' identifying or identified groups in Sikkim as 'backward castes': Gurung, Magar, Newars, Limbu/Subba, Rai, Sunwar, and Tamang. Bengali, Bihari, Deswali, Marwari, and Punjabi -identifying communities, all recent migrants who are diverse both within and among respective communities, are well-established in modern Sikkim [36]. In total, our study recognizes 32 ethnic communities, 17 languages, and 9 religions in Sikkim [34, 36-38].

Sikkim's landscape is a well-recognized biodiversity hotspot, with habitat types broadly categorized into six categories that are correlated elevation (Table 2) [21]. However, extreme topographic variations and Sikkim's horseshoe-shaped geography complicate these generalizations [27]. Some Global 200 Ecoregions found in Sikkim include Himalayan Alpine Meadows and Eastern Himalayan Broadleaf and Coniferous Forests [39]. Diverse assemblages of human communities living within and (re)producing these ecosystems have facilitated the region's rich, biocultural heritage.

\section{Data collection and standardization}

From October 2015 through February 2016, we conducted a systematic review of publically available and accessible literature pertaining to ethnobiological knowledge in the Sikkim Eastern Himalayas. For this study, we defined ethnobiological knowledge as traditional and community knowledge-Indigenous and non-Indigenous-related to socio-ecological interactions between identified or identifiable taxa and the people of Sikkim. Using search terms Darjeeling/Kalimpong/Sikkim/Eastern Himalaya AND Ethno/Indigenous/Traditional, we searched four digital databases: (i) ENVIS [40]; (ii) Google Scholar; (iii) NELUMBO [41]; and, (iv) Project Muse [42]. We included Darjeeling and Kalimpong (West Bengal, India) as place-based keywords due to their historical association with the Kingdom of Sikkim. After analysis, we omitted data published in the ENVIS Medicinal Plants of Sikkim database due to its primary reference of non-Sikkimese user groups and medical traditions. We then conducted archival research at six institutions in Gangtok, Sikkim using the same criteria: (i) The Botanical Survey of India; (ii) The G. B. Pant National Institute of Himalayan Environment and Sustainable Development, Sikkim Unit; (iii) The Namgyal Institute of Tibetology; (iv) Home Department, Government of Sikkim Central Library; (v) Sikkim University Central Library; and, (vii) Sikkim State Bioinformatics Institute. Once collected, each source was reviewed for the following subsets of data: study site name, including the names of sacred landscapes, cities, villages, panchyats, samitis, blocks, districts, and subdivisions; bio-physical characteristics of site-specific studies; publication date; Indigenous and local castes, clans, and groups surveyed; and, species diversity. These sources are provided as an additional file [see Additional file 1].

We transcribed species data from each reviewed record into a working database [see Additional file 2]. After all sources were reviewed, we then standardized species to current taxonomic designations using international databases and field guides [43-48]. Concurrently, we tabulated the relative citation frequency for each species, and partitioned uses into one of 19 accepted categories (Table 2) [49, 50]. Relative citation frequency was calculated by dividing each citation value by the value of the most frequently cited species [see Additional file 2]. Regarding ecological data, we detailed Sikkim-specific altitudinal range data when possible [51-58]; data from the region were used as a proxy in the absence of Sikkim-specific records [45-47, 59-61]. Finally, we collected the following data: the conservation status of species from the IUCN Red List of Threatened Species [62] and Government of Sikkim [63]; and, naturalization, cultivation, or domestication status $[47,64]$. Our study assumes that the number of use categories reported for a given species corresponds with the amount of attention it receives from communities in Sikkim. It is important to note that the number of uses might not correspond to current and active applications of those uses. 
Table 2 Habitat zones in the Sikkim Eastern Himalayas, and some characteristic woody taxa with ethnobotanical records found within associated habitat zones (Adapted from [21, 53])

\begin{tabular}{|c|c|c|c|}
\hline \multirow{2}{*}{$\frac{\text { Habitat Zone }}{\text { Tropical }(<1000 \mathrm{~m})}$} & \multicolumn{2}{|c|}{ Forest Type } & \multirow{2}{*}{$\begin{array}{l}\text { Some characteristic taxa with ethnobotanical records } \\
\text { Bombax ceiba, Cycas pectinata, Dalbergia sissoo, }\end{array}$} \\
\hline & (i) & Tropical riverine evergreen/deciduous Forest & \\
\hline & (ii) & Tropical Moist Evergreen/Deciduous Forest & Dillenia indica, Duabanga grandiflora, Garuga pinnata, \\
\hline & (iii) & Tropical Moist Mixed Forest & Lagerstromia speciosa, Mimosa pudica, Shorea robusta \\
\hline & (iv) & Tropical Dry Evergreen/Deciduous Forest & \\
\hline \multirow{4}{*}{$\begin{array}{l}\text { Subtropical } \\
(1000-2000 \mathrm{~m})\end{array}$} & (i) & Subtropical Riverine evergreen/Deciduous Forest & Callicarpa arborea, Castanopsis tribuloides, Fraxinus floribunda, \\
\hline & (ii) & Subtropical Moist Evergreen/Deciduous Forest & Macaranga pustulata, Mangifera sylvatica, Pandanus furcatus, \\
\hline & (iii) & Subtropical Moist Mixed Forest & Saurauia nepaulensis, Schima wallichi \\
\hline & (iv) & Subtropical Dry Evergreen/Deciduous Forest & \\
\hline \multirow{4}{*}{$\begin{array}{l}\text { Warm Temperate } \\
(2000-2500 \mathrm{~m})\end{array}$} & (i) & Warm Temperate Riverine Evergreen/Deciduous Forest & Alnus nepalensis, Castanopsis tribuloides, Engelhardia spicata, \\
\hline & (ii) & Warm Temperate Moist Evergreen/Deciduous Forest & Evodia fraxinifolia, Ilex dipyrena, Juglans regia, \\
\hline & (iii) & Warm Temperate Moist Mixed Forest & \multirow{2}{*}{$\begin{array}{l}\text { Lithocarpus pachyphyllus, Quercus lamellosa, } \\
\text { Zanthoxylum acanthopodium }\end{array}$} \\
\hline & (iv) & Warm Temperate Dry Evergreen/Deciduous Forest & \\
\hline \multirow{4}{*}{$\begin{array}{l}\text { Cool Temperate } \\
(2500-3000 \mathrm{~m})\end{array}$} & (i) & Cool Temperate Riverine Deciduous Forest & Acer caudatum, Betula utilis, Cinnamomum impressinervium \\
\hline & (ii) & Cool Temperate Moist Evergreen Forest & Cryptomeria japonica, Magnolia lanuginosa, Mahonia sikkimensis, \\
\hline & (iii) & Cool Temperate Moist Mixed Forest & Rhododenron arboreum, Quercus lineata \\
\hline & (iv) & Cool Temperate Dry Evergreen Forest & \\
\hline \multirow{4}{*}{$\begin{array}{l}\text { Subalpine } \\
\text { (3000-4000 m) }\end{array}$} & (i) & Subalpine Riverine Evergreen Forest & Abies densa, Abies spectabilis, Berberis insignis, Juniperus recurva, \\
\hline & (ii) & Subalpine Moist Evergreen Forest & $\begin{array}{l}\text { Larix griffithiana, Rhododenron barbatum, Rhododendron } \\
\text { campanulatum, Taxus wallichiana }\end{array}$ \\
\hline & (iii) & Subalpine Moist Deciduous Forest & \\
\hline & (iv) & Subalpine Dry Evergreen Forest & \\
\hline \multirow[t]{3}{*}{ Alpine (>4000 m) } & (i) & Alpine Riverine & Juniperus indica, Rhododendron fulgens, Rhododendron nivium \\
\hline & (ii) & Alpine Meadow & \\
\hline & (iii) & Alpine Scrub & \\
\hline
\end{tabular}

\section{Data analysis}

We geo-referenced reported study sites and conducted spatio-temporal analyses of reviewed data in ArcGIS [11, $65,66]$. Specifically, we performed the following assessments: (i) identification of administrative districts with the highest representation of ethnobiological records; (ii) temporal analysis of ethnobiological knowledge documentation; and, (iii) identification of surveyed communities and their knowledge documentation through time.

We calculated two conservation ranks for reviewed species based on accepted methods for categorical data (Tables 3 \& 4): Harvest Rank (HR) and Sensitivity Rank (SR) (see $[67,68]$ ). From this point, however, we could not carry out further statistics as our rank assignation was based on qualitative criteria in which numerical ranks represent other categories rather than quantities. The HR value incorporated harvest and provenance data (Table 4): wild and native $(\mathrm{WN})=5$; wild-cultivated and native $(\mathrm{WCN})=4$; wild and non-native $(\mathrm{WNN})=3$; wild-cultivated and nonnative $(\mathrm{CNN})=2$; and cultivated $(\mathrm{C})=1[60,67,69]$. We believe that wild and native species are of higher conservation priority because on their provenance in the Sikkim
Table 3 Criteria for ranking species for Sensitivity Rank (SR) of reviewed species

\begin{tabular}{|c|c|}
\hline Attribute & Attribute Criteria \\
\hline \multicolumn{2}{|l|}{ Species Engagement } \\
\hline High Relative Intensity (D) & $\begin{array}{l}\text { Harvesting/utilizing either (i) whole animal } \\
\text { or animal part in a manner that reduces } \\
\text { animal's lifespan (i.e. bones, ivory, } \\
\text { meat, etc.); or (ii) whole plant, rootstock, } \\
\text { rhizome, fungal body, etc. }\end{array}$ \\
\hline Low Relative Intensity (N) & Species engagement excluding the above \\
\hline \multicolumn{2}{|l|}{ Altitudinal Range } \\
\hline Restricted (R) & Range limited to one habitat zone \\
\hline Wide (W) & $\begin{array}{l}\text { Range extending to two or more habitat } \\
\text { zones (Refer to Table } 2 \text { for habitat zones) }\end{array}$ \\
\hline \multicolumn{2}{|l|}{ Population Status } \\
\hline Threatened (T) & $\begin{array}{l}\text { IUCN or Government of Sikkim- } \\
\text { recommended Critically Endangered (CR), } \\
\text { Endangered (EN), or Vulnerable (VU) }\end{array}$ \\
\hline Not Threatened (U) & $\begin{array}{l}\text { IUCN or Government of Sikkim- } \\
\text { recommended Near Threatened (NT), } \\
\text { Least Concern (LC), or Not Assessed (NA) }\end{array}$ \\
\hline
\end{tabular}


Table 4 The structure of our sensitivity matrix used to rank reviewed species [60, 67-69]

\begin{tabular}{llll}
\hline Sensitivity Rank (SR) & Extraction & Occurrence & Population status \\
\hline 8 & D & R & T \\
7 & D & R & U \\
6 & D & W & T \\
5 & D & W & U \\
4 & N & R & T \\
3 & N & R & U \\
2 & N & W & T \\
1 & N & W & U
\end{tabular}

Abbreviations: (i) Extraction: Destructive Harvesting (D) or Non-destructive Harvesting (N); (ii) Occurrence: Rare (R) or Widespread (W); (iii) Population Status: Threatened (T) or Unthreatened (U). Refer to Table 3 for further elaboration

Eastern Himalaya, and their historical role in regional ecology. The SR value accounted for three important factors determining the conservation status of species: mode and extent of harvesting; altitudinal range, or amplitude; and, (iii) species' population status, based on IUCN Red List of Threatened Species and Government of Sikkim recommendations [60,63]. Using matrix criteria to account for these attributes, we scored SR in a decreasing order to 8-1 (Table 4) [69]. We also calculated a relative citation frequency (CF), or the number of reviewed citations for species $e$ divided by the maximum number of citations for $n$ surveyed species. These data are provided as an additional file [see Additional file 2]. We hope these ranks, although qualitative, serve as platform for future analyses that integrate social and natural science data with community knowledge to indicate priority targets for biodiversity conservation.

Using the altitudinal range of each reviewed species, we modeled biocultural hotspots in Sikkim using a standard methodology at $100 \mathrm{~m}$ altitudinal resolution (Fig. 2) (see [70]). Here, we aimed to project a qualitative map that identified priority regions for biodiversity conservation based on the altitudinal range of reviewed species. We acknowledge that modeling procedures often account for GIS-based, site-specific occurrences and bioclimatic variables associated with specific species [70, 71]. However, such data from Sikkim is only available in heterogeneous, fragmented forms that are geographically biased or incorrect. Moreover, Sikkim's topography, which averages $40^{\circ}$ slope, and altitudinal variation, ranging from $284 \mathrm{~m}$ to $8586 \mathrm{~m}$, generate a plethora of unpredictable microhabitat and microclimatic conditions that: influence species distributions; limit the practicality of field surveys; and, bias conventional modeling procedures [72]. Therefore, in the absence of data, our model engages altitudinal distribution data as the sole proxy for various methodologies [73].

\section{Results}

Spatio-temporal analysis

Our review resulted in 176 ethnobiological records from the Sikkim Eastern Himalayas [see Additional file 1]. These records include 42 site-specific surveys, 18 of which were multi-site studies (total geo-referenced locations: 119), 94 contained methodological or instructional content on species use, 15 contained folk tales or cultural information beyond medical or material utility, and ten were biodiversity-related records with ethnobiological footnotes (Fig. 1). Based on site-specific records, North District received the greatest survey effort (37\%) followed by West District (33\%), East District (16\%), and South District (14\%). North District's survey effort was driven by studies in Dzongu Territory (North District), a once-royal land plot now reserved for certain Lepcha families. The average survey altitude across sitespecific records was 1775 m ASL (+/- 712 m SD).

Our temporal analysis revealed that biocultural records were first published during the East India Company's expansion across the Indian Subcontinent during the 1840s [74-76]. Our review specifies that Sir Archibald Campbell, the first British political officer to Sikkim and Darjeeling, authored the first ethnobotanical vignettes from Sikkim as they relate to Lepcha communities [74]. Concurrently, Sir Joseph Dalton Hooker, a British doctor and an esteemed naturalist, reflected upon the region's biocultural heritage in his two-volume Himalayan Journals published 1854. For much of the mid-19th Century, naturalist records were the primary sources of biocultural anecdotes, particularly as they relate to Rhododendron spp. (see [21]). We identified no biocultural records dating one century after Hooker's Journals. A few generalist surveys were conducted during the mid-20th Century in what was termed the Sikkim and Darjeeling Hills [77, 78]. Approximately $14 \%$ of all ethnobiological records from Sikkim were published between 1854 and 1990, none of which detailed specific study sites (Fig. 2). The late 20th Century saw an exponential increase in these studies across Sikkim, particularly regarding medicinal plant species. Place and district-specific studies revealed that the earliest documentation began in West District, and moved toward North District during the second decade of the 21st Century (Fig. 1). Approximately, 87\% of all reviewed biocultural studies were published between 1990 and 2016, with a significant increase in publication rate during the first decade of the 21 st Century $(r=0.863 ; P<0.001)$.

\section{Surveyed ethnic communities}

Six of 32 identified ethnic communities in Sikkim have written ethnobiological records: Bhutia, Lepcha, Limbu, Nepali, Sherpa, and Tibetan communities. However, most reviewed records were not ethnic-group specific and 


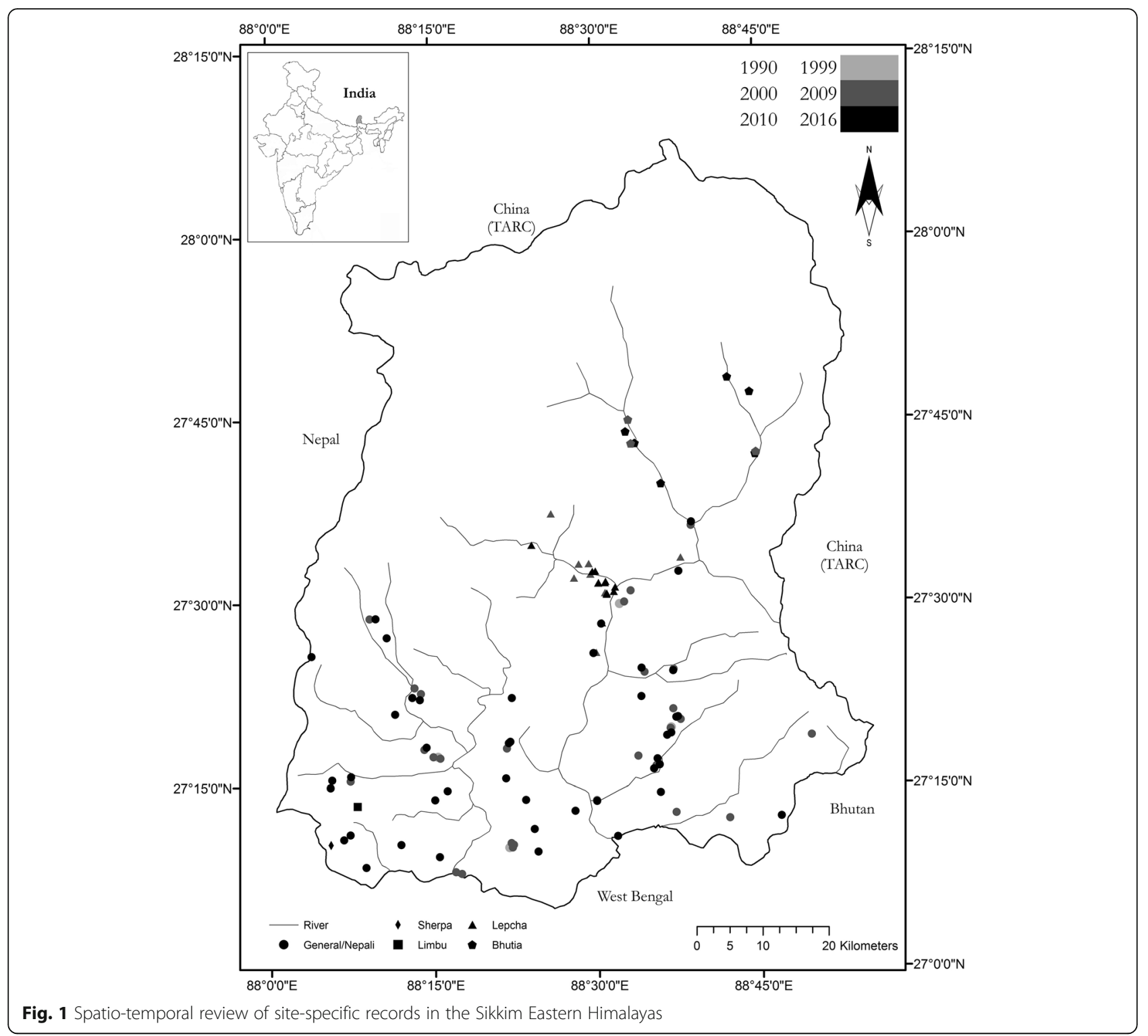

reported data and/or knowledge in Sikkim-vernacular Nepali language. Nepali-identified or identifying groups, including non-specific reports detailed in Nepali language, had the greatest number of identified species (732), followed by Lepchas (377), Limbus (298), Tibetans (120), Bhutias (74), and Sherpas (35). Four categories of male specialized users and spiritual healers were reported from four ethnic communities: Bhutia: Lama; Lepcha: Bomthing, Mon-bomthing; Nepali: Bijuwa, Fedangwa, Jhakri; and, Tibetan: Amchis.

\section{Species diversity}

A total of 1128 species distributed across three kingdoms, 213 families, and 712 genera have ethnobiological records in the Sikkim Eastern Himalaya [see Additional file 2]. Plantae was the most surveyed kingdom (995 species; 625 genera; 160 families), housing $88 \%$ of all reviewed species. Animalia (species: 76; genera: 50; families: 28; 7\% of reviewed species) and Fungae (species: 57; genera: 37 ; families: 25 ; $5 \%$ of reviewed species) exhibited a comparative dearth of records [see Additional file 2]. Across kingdoms, 105 species were considered Himalayan or Eastern Himalayan endemic $[45,79]$. The average range amplitude of species in Animalia was $1098 \mathrm{~m} \mathrm{(+/-1009} \mathrm{m} \mathrm{SD),} \mathrm{in} \mathrm{Fungae} 1683 \mathrm{~m} \mathrm{(+/-} 884 \mathrm{~m}$ $\mathrm{SD})$, and in Plantae $1329 \mathrm{~m}(+/-584 \mathrm{~m} \mathrm{SD})$.

In Plantae, angiosperms were the most explored discipline, accounting for $96 \%$ of all documented plant species (957). Pteridophytes (23), Gymnosperms (10), and Bryophytes (5) received notably less attention in comparison [27]. Five plants were reported as endemic to the Sikkim Eastern Himalayas, namely: Aconitum ferox var. naviculare, 


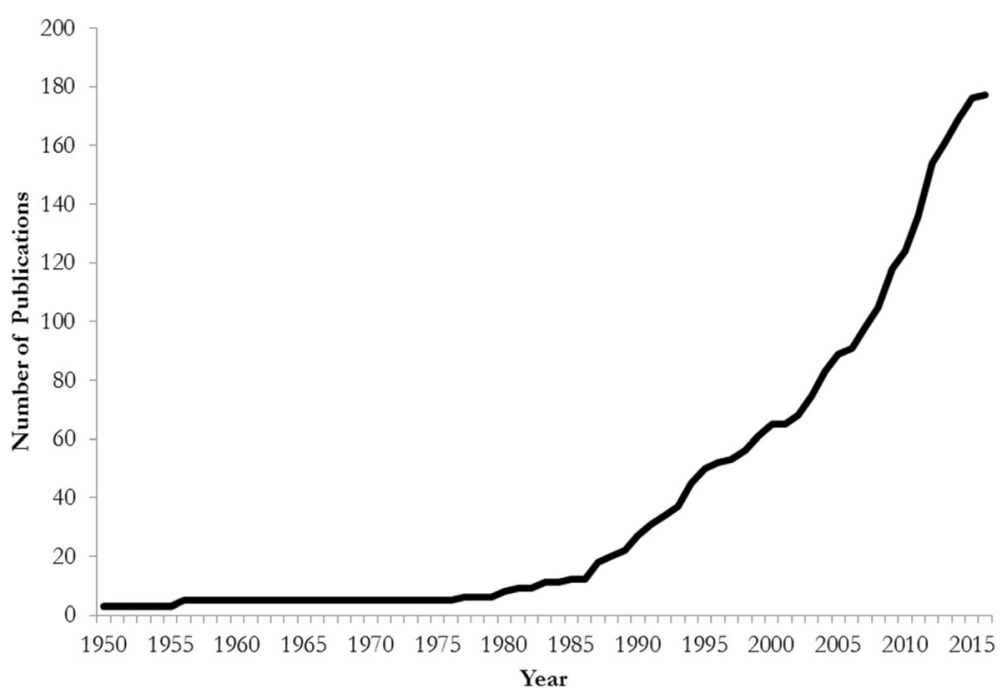

Fig. 2 Publication of ethnobiological records from 1950 to 2016

Allium sikkimense, Mahonia sikkimensis, Rhododendron sikkimensis, and Swertia pedicellata. The taxonomic designations for these and many of our reported species, however, are pending official revision. In Animalia, fish were the most represented Chordates (37), followed by Mammals (22), Birds (12) and Amphibians (3) [see Additional file 2]. Three invertebrates were cited, two of which were in the Apidae. In Fungae, Basidiomycetes accounted for $77 \%$ of reviewed species (44), with approximately $85 \%$ of the remaining 13 Ascomycetes being Lichens.

\section{Ethnobiological uses}

Across kingdoms, species were primarily used as medicine to prevent or manage gastro-intestinal afflictions, dermatological conditions, and respiratory-tract infections (Table 5) [see Additional file 2]. The ten most cited species also occupied the most diverse use categories, respectively: Swertia chirayita (Gentianaceae), Bergenia ciliata (Saxifragaceae), Oroxylum indicum (Bigoniaceae), Uritica dioica (Urticaceae), Acorcus calamus (Acoraceae), Nardostachys jatamansi (Caprifoliaceae), Rhododendron arboretum (Ericaceae), Rumex nepalensis (Polygonaceae), Astilbe rivularis (Saxifragaceae), and Cheilocostus speciosus (Costaceae). Species-wise data are available as an additional file [see Additional file 2].

\section{Conservation ranks}

Wild (CR 5 and 3; 922 species; $82 \%$ total) and native taxa (CR 5; 817; 72\%) were cited more frequently than wildcultivated (CR 4 and 2; 107; 10\%) and cultivated species (CR 1; 99; 8\%). Most species were harvested, cultivated, or used in a sustainable manner (SR 1-4; 642; 57\%) and exhibited altitudinal distributions that crossed multiple habitat types (SR 6-5, 21; 962; 85\%). Of 1128 species, approximately 80 species were both destructively harvested and had restricted ranges. Four of these species also had a threatened status in Sikkim (SR 8), including Cymbidium grandiflorum (Orchidaceae), Flickingeria fimbriata (Orchidaceae), Ophiocordyceps sinensis (Ophiocordycipitaceae), and Tor putitora (Cyprinidae). Based on IUCN Red List of Threatened Species assessments [60], three of all species were Critically Endangered (CR), four are Endangered $(\mathrm{EN})$, seven are Vulnerable $(0.64 ; \mathrm{VU}), 11$ are Near Threatened (1.00\% NT), 99 are of Least Concern (9.03\% LC), and 972 species have not been assessed (88.69\% NA) [see Additional file 2]. An additional 25 species have recommended conservation statuses by the Government of Sikkim based on IUCN-CAMP criteria ([63]; see Additional file 3). These species include exploited medicinal plants such as Swertia chirayita, Nardostachys jatamansi, Picrorhiza kurroa (Plantaginaceae), Sinopodophyllum hexandrum (Berberidaceae), and Valeriana jatamansi (Caprifoliaceae).

\section{Biocultural hotspots}

Our map illustrates areas that have the greatest potential richness of species with biocultural records, termed biocultural hotspots, based on the elevational range of species (Fig. 3). Grid cell values range 7 (low) to 619 (high) species and are presented at $100-\mathrm{m}$ elevational resolution. The highest grid-cell values were located outside of PAs. Richness of culturally important species was highest in subtropical zones across kingdoms, with a sharp decline toward alpine regions.

\section{Discussion}

Our review indicates that Sikkim has a rich biocultural heritage that includes knowledge pertaining to over 1100 species 


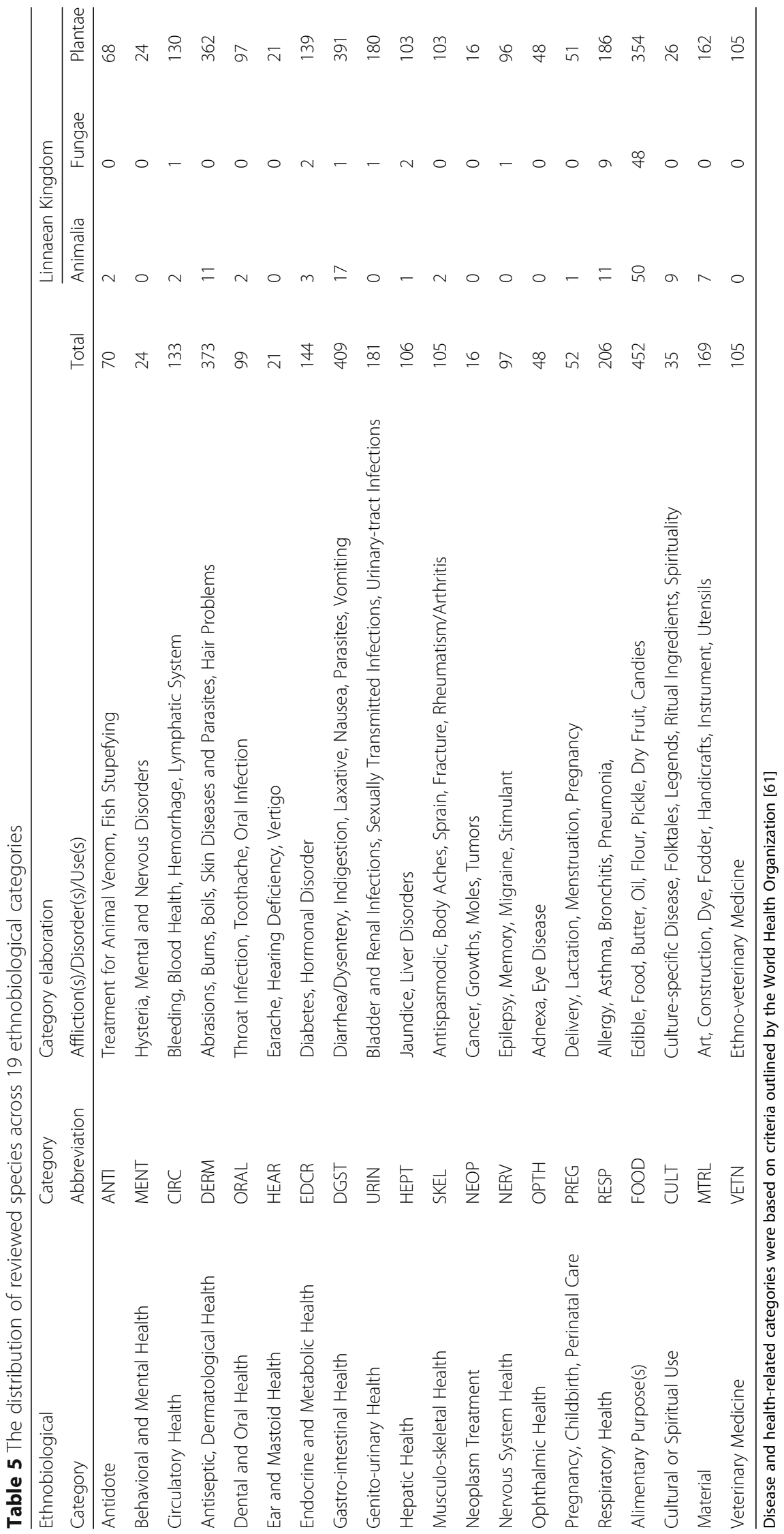




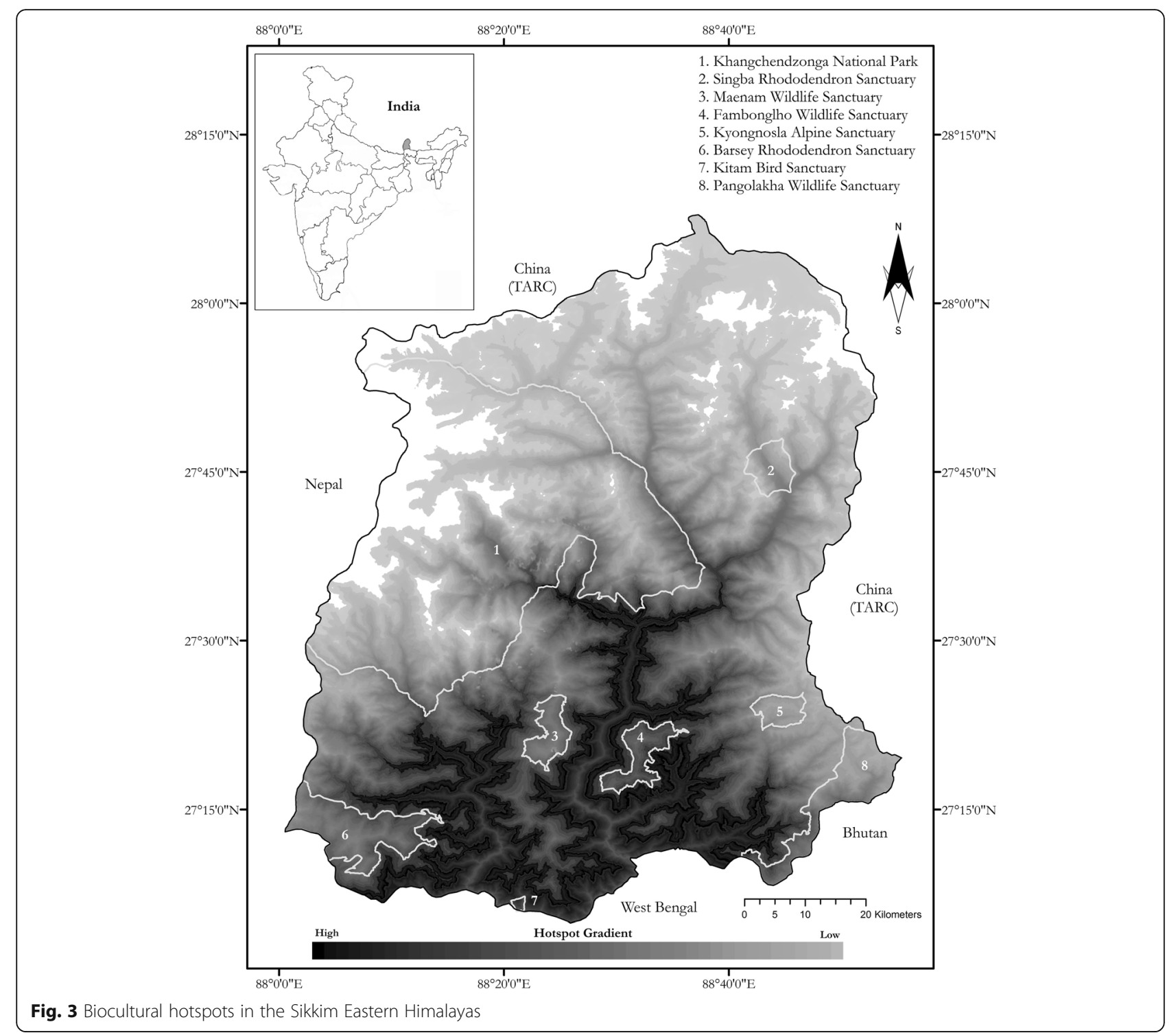

of animals, fungi, and plants. Local people not only know about the useful properties of these species, but also the community ecology and life histories of diverse organisms [80]. These aspects of ethnobiological knowledge, which encompass abundance, distribution, and phenology, significantly influence community management practices and can therefore benefit conservation planning in Sikkim [29, 79]. For instance, in previous studies, Lepcha communities were engaged by government researchers to understand the population status of under-surveyed bird species; local communities were found to provide "data" at the accuracy needed to make management decisions [81, 82]. Our reviewed records also implied that faith traditions and community taboos sustain many ethnobiological relationships in Sikkim, and cultivate a sense of stewardship toward critical habitat $[35,83-86]$. We conclude that targeting biocultural knowledge systems, including gaps in ethnobiological research, is a practical way to incorporate local peoples-their knowledge, land, and participation-into multi-scalar conservation directives in the Eastern Himalayas.

Our analyses illuminated the dynamic nature of ethnobiological knowledge, and evidenced its ongoing construction amidst changing socio-ecological conditions. We traced a dramatic increase in ethnobiological records published since the 1950s, with a significant spike in the mid-1990s. This trend appears correlated with both the relaxation of permit restrictions into Sikkim, and the 1993 initiation of the Convention on Biological Diversity (CBD) following the Earth Summit in Rio de Janeiro in 1992. The CBD obliged signatory polities, including India, to acknowledge and preserve 
biocultural knowledge as an adaptive resource for conservation initiatives, record and disseminate biocultural knowledge for practical applications, and ensure equitable benefits arising from biocultural knowledge (reviewed by [21]). Our assessment highlighted, however, a stark difference in ethnobiological knowledge within and among ethnic communities. Intra-cultural differences compounded overall knowledge diversity based on age, gender, occupation, and individual strategies and interests [26]. These factors were not quantitatively justified in any of our reviewed studies. The paucity of records from 26 identified ethnic communities further indicates that much of Sikkim's biocultural heritage remains as unwritten, oral traditions situated within a gendered, caste-specific, and aging stratum of society. In the future, we suggest that researchers begin addressing these gaps through collaborations with nomadic or semi-nomadic peoples at high altitudes, including Bhutia, Chumbipa, Dopthapa, Drokpa, Kagate, Sherpa, Tromopa and Yolmo communities. High-altitude zones are particularly sensitive to climatic changes that may alter community assemblages, ecological processes, and, as an extension, historical ways of relating to the environment $[85,87,88]$. With the participation of these groups, conservationists can craft more holistic and culturally appropriate strategies for both restoration and conservation in the Eastern Himalayas.

As previously alluded to, older members of rural communities were the primary user group of reviewed species, namely for medicine. Knowledge of species use, practice, and folklore was reported to decrease in recent generations, as much of the knowledge was documented from collaborators between 50 and 70 years of age [26, 29]. Today, younger generations migrate to urban centers where they are neither exposed to local species nor the traditions that surround them. Both imposed legal structures in the early 21st Century and market liberalization in the mid-1990s have further complicated knowledge transmission and species use, resulting in the attrition of ethnobiological knowledge in Sikkim. For instance, between the 1970s and 1990s, the Sikkim Forest, Environment and Wildlife Management Department permitted commercial exploitation of medicinal plants, including from PAs. However, as of 2001, the government implemented a 5-year ban on medicinal plant collection via Order No. 13/F/Env\&W. This order received a 5 -year extension in 2006, and will likely be ratified again in the future. Moreover, local access to state healthcare providers and allopathic medicine has reduced local dependency on wild animals, fungi, and plants as medicine.

Despite the decreased reported use of medicinal plants, many wild species remain a vital part of Sikkimese cuisine [89-94]. Local communities have regular access to wild edibles at markets in the cities of Gangtok (East District),
Geyzing (West District), Namchi (South District), and Singtam [91, 93, 95]. Various ferns (Diplazium spp.; Athyriaceae), the Sikkim Cobra Lily (Arisaema utile; Araceae), and Stinging Nettles (Uritica dioica; Urticaceae) were some frequently cited edibles, and were often prepared alongside pickled vegetables, like Nodding Tupistra (Tupistra nutans; Asparagaceae), in traditional Sikkimese cuisine [96-99]. Fruits from Bastard Oleaster (Elaeagnus latifolia; Elaeagnaceae), Burmese Grape (Baccaurea ramiflora; Phyllanthaceae), and Machilus edulis (Lauraceae) were also seasonal favorites with high reported consumption [100-102]. Regarding Fungae, commercial cultivation has increased in lower-altitude zones, particularly of species in the genera Agaricus and Pleurotus [51, 52, 103]. Wild animals were also consumed for medicinal purposes, albeit at low reported frequency and only in rural contexts. The meat of Asian Black Bear (Ursus thibetanus; Ursidae), Bengal Fox (Vulpes bengalensis; Canidae), Central Himalayan Langur (Semnopithecus schistaceus; Cercopithecidae), Himalayan Crestless Porcupine (Hystrix brachyura; Hystricidae), and Hodgson's Giant Flying Squirrel (Petaurista magnificus; Sciuridae) were reported to treat respiratory diseases, namely Tuberculosis, which are common in Sikkim [87104]. Fish are available in most market places, and have high reported consumption; however, their populations likely face threats from hydroelectric dam development in Sikkim $[105,106]$. Future studies should quantify the value and quantity of wild edibles sold in marketplaces to better understand anthropogenic pressures on wild populations and expand wild-cultivation practices when possible.

Incentivizing and/or commercializing the cultivation of edible and medicinal plants and fungi within agroforestry systems may reduce pressure on wild populations and create habitat corridors for threatened species [29, 107]. To date, most conservation efforts in Sikkim have been directed toward the nominal designation of PAs at mid and high altitudes. Military encampments and agricultural landscapes surround these PAs. Moreover, traditional doctors, spiritual healers, and rural villagers still harvest and collect many reviewed species from these areas despite legal restrictions [104, 108-112]. Conservationists can begin addressing these pressures, without marginalizing local communities, by promoting cooperative agroforestry programs along PA borders. Recent reviews, for example, have suggested integrating edible and medicinal plant cultivation into existing Nepalese Paperbush (Edgeworthia gardneri; Thymelaeaceae) or Black Cardamom (Amomum subulatum; Zingiberaceae) agroforestry systems which already yield high profits $[29,113,114]$. As noted by Charnley et al. [115], such programs must do more than identify the "right" or best model for knowledge application and sharing, and must address existing societal factors that may hinder program implementation or undermine community structures. Organizational 
frameworks could, therefore, draw upon pre-existing dzumsa and $d$ wichi committee structures in Sikkim, which have legacies of conservation impact $[116,117]$. Any cooperative, however, must ensure that agroforestry systems produce marketable amounts of edibles that can either be preserved or transported to market before spoilage (as reviewed by $[29,116])$. Our conservation rank system and additional files is useful for identifying target species based on criteria of interest, including medicinal use, altitudinal range, and population status [see Additional files 1, 2 and 3].

Incorporating ethnobiological knowledge into biodiversity conservation is a meaningful way to empower local communities to both monitor and preserve species of biocultural importance [9, 11, 116]. Based on our review, communities have obvious incentive to conserve biodiversity for cultural purposes and practical use. However, our results suggest a literature bias toward medicinal plants, and a paucity of records from the kingdoms Animalia and Fungae. To hone the applicability of our biocultural hotspot concept, we recommend that researchers incorporate new criteria, including species-specific ranges and habitat information, into our model structure. Moreover, we suggest that researchers document ethnobiological relationships that extend beyond medicinal uses of species to include living oral traditions, folklore, art, etc. By combining ethnobiological surveys with biodiversity science, particularly the gaps noted in recent reviews [21, 29], conservationists can better understand the socio-ecological dynamics shaping modern Sikkim.

\section{Conclusion}

We collated and applied ethnobiological knowledge to promote biodiversity conservation in the Eastern Himalayas. We began with a spatio-temporal review of biocultural records from Sikkim, India to understand: (i) patterns in biocultural knowledge documentation; (ii) the diversity of species with biocultural records; and (iii) the partitioning of biocultural knowledge within and among ethnic communities. We then galvanized these records into two conservation indices and a biocultural hotspot model that indicate conservation priorities in Sikkim.

\section{Additional files} Additional file 1: Ethnobiological records reviewed by this manuscript.
(PDF $147 \mathrm{~kb}$ )

Additional file 2: Reviewed species with ethnobiological records, including rank values, distributional data, ethnobiological uses. (XLSX 126 kb)

Additional file 3: Some threatened species in the Sikkim Eastern Himalaya. (XLSX $12 \mathrm{~kb})$

\section{Acknowledgement}

We would like to thank our collaborators at the United States India Education Foundation (USIEF) and the United States William J. Fulbright Commission for their support and inspiration under a Fulbright-Nehru Research Fellowship awarded to $A R O$ at the G. B. Pant National Institute for Himalayan Environment and Sustainable Development (GBPNIHESD). ARO and HKB are highly grateful to the Director of the Institute for providing necessary facilities and support at the Sikkim Unit. We would also like to extend our gratitude to Jhony Lepcha, a Researcher at the Sikkim Unit (GBPNIHESD), for his help generating our manuscript figures. ARO would like to extend gratitude to L. Lepcha, Sikkim State Council of Science \& Technology, and T. Cho Cho and P. Gurung, Sikkim State Home Department, for their assistance during our research period.

\section{Funding}

This research was funded by a Fulbright-Nehru Research Scholarship granted to ARO by the United States-India Education Foundation (USIEF) and the Institute for International Education (IIE). Funding agencies did not participate in any aspect of project design, study implementation, data interpretation, or manuscript preparation.

\section{Availability of data and materials}

All data and material is available as our Additional files 1, 2, and 3, which is clearly noted throughout our manuscript.

\section{Authors' contributions}

$A R O, H K B, P P D$, and SKR participated in study design and implementation. $A R O$ and $H K B$ conceived the study, and $A R O$ prepared the manuscript. $A R O$, HKB, PPD, SKR collected and standardized data for analysis. All authors read and approved the final manuscript.

\section{Competing interests}

The authors declare that they have no competing interests.

\section{Consent for publication}

The authors of this manuscript consent for publication.

\section{Ethics approval and consent to participate}

Our study is exempt from IRB approval because it is a review of literature. As such, there was no need to request consent for participation in our study.

\section{Author details}

${ }^{1}$ Fulbright-Nehru Research Scholar, United States-India Education Foundation (USIEF) and the United States Fulbright Commission, Washington, DC, USA.

${ }^{2}$ G. B. Pant National Institute of Himalayan Environment and Sustainable Development, Sikkim Unit, Pangthang, Gangtok, East Sikkim, Sikkim 737 102, India. ${ }^{3}$ G. B. Pant National Institute of Himalayan Environment and Sustainable Development, Kosi-Katarmal, Almora, Uttarakhand 263 643, India. ${ }^{4}$ Central

Department of Botany, Plant Systematics and Biodiversity, Tribhuvan University, Kirtipur, Kathmandu 44618, Nepal.

Received: 30 December 2016 Accepted: 21 February 2017 Published online: 29 March 2017

\section{References}

1. Maffi L. On biocultural diversity: linking language, knowledge, and the environment. Washington: Smithsonian Institution Press; 2001.

2. McShane TO, Hirsch PD, Trung TC, Songorwa AN, Kinzing A, Monteferri B, et al. Hard choices: making trade-offs between biodiversity conservation and human well-being. Biol Conserv. 2011; doi:10.1016/j.biocon.2010.04.038.

3. Sarkar S, Montoya M. Beyond park and reserves: the ethics and politics of conservation with a case study from Peru. Biol Conserv. 2011; doi:10.1016/j. biocon.2010.03.008.

4. Wilshusen PR, Brechin SR, Fortwangler $C L$, West PC. Reinventing a square wheel: critique of a resurgent "protection paradigm" in international biodiversity conservation. Soc Nat Resour. 2002; doi:10.1080/ 089419202317174002.

5. Adams WM, Hutton K. 2007 People, parks and poverty: political ecology and biodiversity conservation. Conserv Soc. 2007; URL: http://www. conservationandsociety.org/text.asp?2007/5/2/147/49228.

6. Ellis EC, Ramankutty N. Putting people on the map: anthropogenic biomes of the world. Fron Ecol Environ. 2008; doi:10.1890/070062.

7. Doak DF, Bakker VJ, Goldstein BE, Hale B. What is the future of conservation? Trends Ecol Evolut. 2014; doi:10.1016/j.tree.2013.10.013. 
8. Rotherman ID. Bio-cultural heritage and biodiversity: emerging paradigms in conservation and planning. Biodivers Conserv. 2015; doi:10.1007/s10531015-10065.

9. Gavin MC, McCarter J, Mead A, Berkes F, Stepp JR, Peterson D, et al. Defining biocultural approaches to conservation. Trends Ecol Evolut. 2015; doi:10.1016/j.tree.2014.12.005.

10. Maffi L. Biocultural diversity and sustainability. In: Pretty J, Ball AS, Benton T, Guivant J, Lee DR, Orr D, et al., editors. The Sage handbook of environment and society. London: SLE Pound; 2007. p. 267-77.

11. Ens EJ, Pert P, Clarke PA, Budden M, Clubb L, Doran B, et al. Indigenous biocultural knowledge in ecosystem science and management: review and insight from Australia. Biol Conserv. 2015; doi:10.1016/j.biocon.2014.11.008.

12. Blanco J, Carriere SM. Sharing local ecological knowledge as a human adaptation strategy to arid environments: evidence from an ethnobotany survey in Morocco. J Arid Environ. 2016; doi:10.1016/j.jaridenv.2015.10.021.

13. Loh J, Harmon D. A global index of biocultural diversity. Ecol Indic. 2005; doi:10.1016/j.ecolind.2005.02.005

14. Reed MS. 2008. Stakeholder participation for environmental management: a literature review. Biol Conserv. 2008; doi:10.1016/j.biocon.2008.07.014.

15. Berkes F. 2004. Rethinking community-based conservation. Conserv Biol. 2004; doi:10.1111/j.1523-1739.2004.00077.x.

16. Berkes F, Colding J, Folke C. Rediscovery of traditional ecological knowledge as adaptive management. Ecol Appl. 2000; http://www.jstor.org/stable/ 2641280.

17. Rutte $\mathrm{C}$. The sacred commons: conflicts and solutions of resource management in sacred natural sites. Biol Conserv. 2011; doi:10.1016/j. biocon.2011.06.017.

18. Phuntsho K, Chettri N, Oli K. Mainstreaming community-based conservation in a transboundary mountain landscape: lessons from Khangchendzonga. Kathmandu: International Centre for Integrated Mountain Development; 2012.

19. Chettri N, Sharma E. Prospective for developing a transboundary conservation landscape in the Eastern Himalayas. In: McNeely JA, McCarthy TM, Smith A, Olsvig-Whittaker L, Wikramanayake ED, editors. Conservation biology in Asia. Kathmandu: Society for Conservation Biology Asia Section and Resources Himalaya; 2006. p. 2006.

20. Chettri N, Shakya B, Sharma E. Biodiversity conservation in the Khangchenjunga Landscape. Kathmandu: International Centre for Integrated Mountain Development; 2008.

21. Kandel P, Gurung J, Chettri N, Ning W, Sharma E. Biodiversity research trends and gap analysis from a transboundary landscape, Eastern Himalayas. J Asia Pac Biodivers. 2016; doi:10.1016/j.japb.2015.11.002.

22. ICIMOD, WCD, GBPIHED, RECAST, MoFSC. Kangchenjunga landscape conservation and development initiative, feasibility assessment report regional synthesis. 2015. Draft Report.

23. Carlsson L, Berkes F. Co-management: concepts and methodological implications. J Environ Manage. 2005; doi:10.1016/j.jenvman.2004.11.008.

24. Salafsky N, Wollenberg E. Linking livelihoods and conservation: a conceptual framework and scale for assessing the integration of human needs and biodiversity. World Dev. 2000; doi:10.1016/S0305-750X(00)00031-0.

25. Badola HK, Lepcha J, Gaira KS, Sinha S, Dhyani PP. Socio-economic and bioresource assessment: participatory and household survey methods, tools and techniques. New Delhi: Highlanders Communications Private; 2016.

26. Pradhan BK, Badola HK. Ethnomedicinal plant use by Lepcha tribe of Dzongu Valley, bordering Khangchendzonga Biosphere Reserve, in North Sikkim, India. J Ethnobiol Ethnomed. 2008; doi:10.1186/1746-4269-4-22.

27. Government of Sikkim. Sikkim biodiversity action plan. Gangtok: Forest, Environment and Wildlife Management Department; 2012.

28. Brook RK, McLachlan SM. Trends and prospects for local knowledge in ecological and conservation research and monitoring. Biodivers Conserv. 2008; doi:10.1007/s10531-008-9445-X.

29. Uprety Y, Poudel RC, Gurung J, Chettri N, Chaudhary RP. Traditional use and management of NTFPs in Kangchenjunga Landscape: implications for conservation and livelihoods. J Ethnobiol Ethnomed. 2016; doi:10.1186/ s13002-016-0089-8.

30. Duff A. Sikkim: requiem for a Himalayan kingdom. London: Random House; 2015.

31. Sivaramakrishnan K. Modern forests: statemaking and environmental change in colonial Eastern India. Stanford: Stanford University Press; 1999.

32. Turin M. Results from the linguistic survey of Sikkim: mother tongues in education. In: Balikci-Denjongpa A, McKay A, editors. Buddhist Himalaya: studies in religion, history and culture, vol. 2. Gangtok: Namgyal Institute of Tibetology; 2011. p. 127-42.

33. Government of India. The census of India. New Delhi: Ministry of Home Affairs; 2011.

34. Singh KS. Sikkim. In: Dhamala RR, Rai CD, Dutta MS, Ghatak S, editors. People of India, vol. 24. Kolkata: Anthropological Survey of India; 1993.

35. Balikci A. Lamas, shamans and ancestors: village religion in Sikkim. Leiden: Koninklijke Brill; 2008.

36. Government of Sikkim. Sikkim human development report. New Delhi: Routledge; 2015.

37. Tshering SD. Socio-economic census of Sikkim: religious aspects. In: BalikciDenjongpa A, McKay A, editors. Buddhist Himalaya: studies in religion, history and culture, vol. 2. Gangtok: Namgyal Institute of Tibetology; 2011. p 233-44.

38. Government of India. Linguistic survey of India: Sikkim. New Delhi: Office of the Registrar General, Language Division; 2015.

39. Wikramanayake $E_{\text {, Dinerstein }}$, Loucks CJ. Terrestrial ecoregions of the IndoPacific: a conservation assessment. Washington: Island Press; 2001

40. ENVIS. Medicinal plants of Sikkim. Gangtok: Government of Sikkim; 2016. http://envis.frlht.org/sikkim/.

41. Botanical Survey of India. NELUMBO. 2016; http://bsi.gov.in/DetailsArchive/9 5_NOTICEINVITINGFOREXPRESSIONONTSTFORONLINEJOURNALMANAGEMENT SYSTEMINNELUMBOANDAKINGFNELUMBOASE-JOURNAL.aspx.

42. The Johns Hopkins University Press and The Milton S. Eisenhower Library. Project Muse. 2016; https://muse.jhu.edu/.

43. Sharma S, Pandit M. A new species of Panax L. (Araliaceae) from Sikkim Himalaya, India. Syst Bot. 2009; doi:10.1600/036364409788606235.

44. Panda S. Gaultheria stapfiana (Ericaceae), a species to be recognized: insights from morphology, lead anatomy and pollen morphology. Phytotaxa. 2012

45. efloras. Annotated checklist of the flowering plants of Nepal. 2015; http:// efloras.org/flora_page.aspx?flora_id=110.

46. Encyclopedia of Life. EOL. 2016; http://www.eol.org/.

47. Global Biodiversity Information Facility. GBIF. 2016; http://www.gbif.org/.

48. The Plant List. 2016. The plant list. V.1.1. 2016; http://www.theplantlist.org/

49. World Health Organization. International Classification of Diseases (ICD). 2016; URL: http://www.who.int/classifications/icd/en/.

50. da Costa Quinteiro MM, Tamashiro AMG, Santos MG, Pinto LJS, de Morales MG. Inventory and implications of plant use for environmental conservation in Visconde de Maua, Serra da Mantiqueira, Brazil. Ethnobot Res Appl. 2015.

51. Saklani A, Upreti D. Folk uses of some lichens in Sikkim. J Ethnopharmacol. 1992; doi:10.1016/0378-8741(92)90038-S.

52. Adhikari M, Devkota S, Tiwari R. Ethnomycological knowledge on uses of wild mushrooms in Western and Central Nepal. Our Nature. 2005; doi:10. 3126/on.v3i1.329.

53. Das K. Mushrooms of Sikkim: Barsey Rhododendron Sanctuary. Gangtok: Sikkim State Biodiversity Board; 2009.

54. Borah TR, Rahman H. Mushrooms in biodiversity and food security of Sikkim. In: Arrawatia ML, Tambe S, editors. Biodiversity of Sikkim: exploring and conserving a global hotspot. Gangtok: Department of Information and Public Relations, Government of Sikkim; 2011. p. 29-42.

55. Dash SS, Singh P. Trees of Sikkim. In: Arrawatia ML, Tambe S, editors. Biodiversity of Sikkim: exploring and conserving a global hotspot. Gangtok: Department of Information and Public Relations, Government of Sikkim; 2011. p. 89-125.

56. Sinha S, Biswas M. Evaluation of antibacterial activity of some lichen from Ravangla, Sikkim, India. Int J Pharma Biosci. 2011;2(4):23-8.

57. Sinha GP, Ram TAM. 2011. Lichen diversity in Sikkim. In: Arrawatia ML, Tambe S, editors. Biodiversity of Sikkim: exploring and conserving a global hotspot. Department of Information and Public Relations, Government of Sikkim; 2011. p. 13-28.

58. Tamang DK, Dhakal D, Gurung S, Sharma NP, Shrestha DG. Bamboo diversity, distribution patterns and its uses in Sikkim (India) Himalaya. 2013;3(2):1-6.

59. Devkota S. Distribution and status of highland mushrooms: a study from Dolpa, Nepal. J Nat Hist Museum. 2008;23:51-9.

60. Baniya CB, Solhoy T, Gauslaa Y, Palmer MW. The elevation gradient of lichen species richness in Nepal. Lichenol. 2010; doi:10.1017/S0024282909008627.

61. Aryal HP, Budathokio U. Macro-fungi of Karhiya community forest, Western Terai, Nepal. Nepal J Biosci. 2013;2:93-7.

62. International Union for the Conservation of Nature. The IUCN Red List of Threatened Species. Version 2015 - 4. 2016; http://iucnredlist.org/. 
63. Government of Sikkim. Medicinal plant species of conservation concern identified for Sikkim (SK). Gangtok: ENVIS Centre on Conservation of Medicinal Plants. 2014; http://envis.frlht.org/documents/sikkim-medicinalplants-2014.pdf.

64. Gurung B. The medicinal plants of the Sikkim Himalaya. Chakung: Maples; 2008.

65. Google. Sikkim. Google Earth Pro. V 7.1. 2015; URL: http://www.google.com/ earth/download/gep/agree.html.

66. Environmental Systems Research Institute. ArcGIS Desktop. Version 9.3. Redlands, California; 2011.

67. Dhar U, Rawal RS, Upreti J. Setting priorities for conservation of medicinal plants: a case study in Indian Himalaya. Biol Conserv. 2000; doi:10.1016/ S0006-3207(00)00010-0.

68. de Oliveira RLC, Lin Neto EMF, Araújo EL, Albuquerque UP. Conservation priorities and population structure of woody medicinal plants in an area of Caatinga vegetation (Pernambuco State, NE Brazil). Environ Monit Assess. 2007; doi:10.1007/s10661-006-9528-7.

69. Sekar KC. 2012. Invasive alien plants of Indian Himalayan region: diversity and implication. Am J Plant Sci. 2012; doi:10.4236/ajps.2012.3202.

70. Gaikwad J, Wilson PD, Ranganathan S. 2011. Ecological niche modeling of customary medicinal plant species used by Australian Aborigines to identify species-rich and culturally valuable areas for conservation. Ecol Model; doi: 10.1016/j.ecolmodel.2011.07.005.

71. Balram S, Dragićević S, Meredith T. A collaborative GIS method for integrating local and technical knowledge in establishing biodiversity conservation priorities. Biodivers Conserv. 2004; doi:10.1023/B:BIOC. 0000018152.11643.9c.

72. Millette TL, Tuladhar AR, Kasperson RE, Turner BL II. The use and limits of remote sensing for analyzing environmental and social change in the Himalayan middle mountains of Nepal. Global Environ Change. 1995; doi:10. 1016/09593780(95)00071-U.

73. Zainiewski AE, Lehmann A, Overton JMcC. Predicting species spatial distributions using presence-only data: a case study of native New Zealand ferns. Ecol Model. 2003; doi:10.1016/S0304-3800(02)00199-0 $\geq$

74. Campbell A. Note on the Lepchas of Sikkim, with a vocabulary of their language. J Asian Soc Bengal. 1840:9:379-93.

75. Hooker JD. The Rhododendrons of the Sikkim-Himalaya. London: Bentham and Reeve; 1849 .

76. Hooker JD. Himalayan journals: notes of a naturalist in Bengal, the Sikkim and Nepal Himalayas, the Khasia Mountains, etc. London: John Murray; 1855.

77. Basu K. Common medicinal plants of Darjeeling and Sikkim. Kolkata: West Bengal Press; 1956.

78. Biswas K. Common medicinal plants of Darjeeling and the Sikkim Himalayas. Alipore: West Bengal Government Press; 1956.

79. Vallejo-Ramos M, Moreno-Calles Al, Casas A. TEK and biodiversity management in agroforestry systems of different socio-ecological contexts of the Tehuacan Valley. J Ethnobiol Ethnomed. 2016; doi:10.1186/s13002 016-0102-2.

80. Tamsang KP. Glossary of Lepcha medicinal plants. Kalimpong: Mani Printing Press; 2004.

81. Acharya BK, Chettri B, Vijayan L. Indigenous knowledge of Lepcha community for monitoring and conservation of birds. Indian J Tradit Knowl. 2009;8(1):65-9.

82. Chettri N, Sharma E. 2009. A scientific assessment of traditional knowledge on firewood and fodder values in Sikkim, India. Forest Ecology and Management. 2009; doi:10.1016/j.foreco.2009.02.002.

83. Dash SS. Useful plants of Kabi Sacred Grove, Sikkim. NELUMBO. 2007.

84. Bhasin V. Ecology, culture, and change: tribals of Sikkim Himalaya. New Delhi: Inter-India Publications; 1989.

85. Bhasin V, Srivastava VK. Ecology and culture of the Bhutias of North Sikkim. J Human Ecol. 1990;1(3):277-85.

86. Bhasin V. Medical anthropology: healing practices in contemporary Sikkim. In: Bhasin V, Bhasin M, editors. Anthropology today: trends, scope and applications, vol. 3. New Delhi: Kamala-Raj Enterprises; 2007. p. 59-94.

87. Lachungpa $U$. Indigenous lifestyles and biodiversity conservation issues in North Sikkim. Indian J Tradit Knowl. 2009; URL: http://www.nopr.niscair.res. in/bitstream/123456789/.../IJTK8(1)51-55.pdf.

88. Bhasin V. Pastoralists of Himalayas. J Biodivers. 2013;4(2):83-113.

89. Sundriyal M, Rai LK. Wild edible plants of the Sikkim Himalaya. J Hill Res. 1996;9(2):267-78.
90. Sundriyal M, Sundriyal R. Underutilized edible plants of the Sikkim Himalaya: need for domestication. Cur Sci. 2003; URL: http://www.iisc.ernet.in/currsci/ sep252003/731.pdf.

91. Sundriyal M, Sundriyal R. Wild edible plants of the Sikkim Himalaya: marketing, value addition and implications for management. Econ Bot. 2004; doi:10.1163/0013-0001(2004)058.

92. Avasthe RK, Kumar A, Rahman H. Edible horticultural crop diversity in Sikkim Himalaya. In: Sikkim biodiversity: significance and sustainability. Gangtok: Sikkim State Council of Science and Technology; 2012. p. 20-32.

93. Sundriyal M, Sundriyal $R$, Sharma E. Dietary use of wild plant resources in the Sikkim Himalaya, India. Econ Bot. 2004;58(4):626-38.

94. Sundriyal M, Sundriyal R, Sharma E, Purohit A. Wild edibles and other useful plants from the Sikkim Himalaya, India. Oecol Mont. 1998;7(1-2):43-54.

95. Dash SS, Maiti A, Rai SK. Traditional uses of plants among the urban population of Gangtok, Sikkim. J Econ Taxon Bot. 2003:27(1):317-24.

96. Tamang B, Tamang J. Traditional knowledge of bio-preservation of perishable vegetable and bamboo shoots in Northeast India as food resources. Ind J of Tradit Knowl. 2009; URL: http://www.niscair.res.in/ sciencecommunication/researchjournals/rejour/ijtk/Fulltextsearh/2009/ January2009/IJTK-Vol8(1)-January2009-pp89-95.htm.

97. Tamang JP, Thapa S, Tamang N, Rai B. Indigenous fermented food beverages of Darjeeling hills and Sikkim: process and product characterization. J Hill Res. 1996;9(2):401-11.

98. Yonzan H, Tamang JP. Consumption pattern of traditional fermented foods in the Sikkim Himalaya. J Hill Res. 1998;11(1):112-5.

99. Singh HB, Jain A. Ethnobotanical observation on the preparation of Millet beer in Sikkim state, India. J Econ Taxon Bot. 1999;23(2):577-9.

100. Sundriyal M, Sundriyal R. Seedling growth and survival of selected wild edible fruit species of the Sikkim Himalaya, India. Acta Oecol. 2005; doi:10. 1016/j.actao.2005.02.003

101. Chheri N, Sharma E. Non-timber forest produce: utilization, distribution, and status in the Khangchendzonga Biosphere Reserve, Sikkim, India. In: Arrawatia ML, Tambe S, editors. Biodiversity of Sikkim: exploring and conserving a global hotspot. Department of Information and Public Relations, Government of Sikkim; 2011. p. 165-83.

102. Chhetri N, Sharma E, Lama S. Non-timber forest produces utilization, distribution, and status in a trekking corridor of Sikkim, India. Lyonia. 2005; URL: http://www.lyonia.org/downloadPDF.php?pdfID=143.

103. Das K. Promising wild mushrooms from Sikkim Himalaya with ethnomycological significance and potentialities. In: Kumar S, editor. Ethnobotanical studies in India. New Delhi: Deep Publications; 2014. p. 168-86.

104. Rai PC. The practice of traditional healing and the healers of Ribdi-Bhareng. Gangtok: Village Health Association of Sikkim; 2010.

105. Acharjee M, Roy D. Rong ichthyological knowledge: a leeway. King Gaeboo Aachyok. 2013;4:25-34.

106. Tamang P. Ichthyo-faunal diversities of Sikkim: Taxonomic list, fisheries trend, and conservation exigencies. In: Sikkim biodiversity: significance and sustainability. Gangtok: Sikkim State Council of Science and Technology; 2012. p. 170-9.

107. Rai LK, Prasad P, Sharma E. Conservation threats to some important medicinal plants of the Sikkim Himalaya. Biol Conserv; 2010. doi:10.1016/ S0006-3207(99)00116-0.

108. Chettri A, Barik SK. Assessing ethnobotanical value and threat status of Tetrastigma rumicispermum (Lawson) Planch, a lesser known liana species of Khangchendzonga Biosphere Reserve, Sikkim. Ind J Trad Know. 2013; URL: http://14.139.47.15/handle/123456789/16852.

109. Chhetri DR. Ethnomedicinal plants of the Khangchendzonga National Park, Sikkim, India. Ethnobot. 2005; URL: http://14.139.206.50:8080/jspui/handle/1/ 3649.

110. Dhakal RD, Sharma G, Basnet K. Study of community dependence on Menam Wildlife Sanctuary in the Sikkim Himalayas. J Hill Res. 2006;19(1):24-33.

111. Lepcha S, Das A. Ethno-medico-botanical exploration along the international borders to Tibet Autonomous Region of China and the kingdom of Bhutan with special reference to the Pangolakha Wildlife Sanctuary, East Sikkim. In: Ghosh C, Das AP, editors. Recent studies in biodiversity and traditional knowledge in India. Malda: Gour College Press; 2011. p. 257-70.

112. Shrestha B, Basnett $H$, Prosanta P. Herbal remedies practiced by traditional practitioners of Nepali tribe in Sikkim. Uni J Pharma Sci Res. 2015; http:// ujpsr.com/sites/default/files/articles/UJPSRMNSC-1\%281\%29.pdf.

113. Borah TR, Avasthe R, Helim R. Large Cardamom (Amomum sublatum): a traditional cash crop of Sikkim. Asian Ag Hist. 2012;16(3):271-7. 
114. Kumar S, Raju DCS. Large Cardamom and its wild relatives in Sikkim Himalayas. J Hill Res. 1998;2(2):375-79.

115. Kumar S, Singh P, Singh V. Ethnobotanical aspects of some arboreal and arborescent taxa of Sikkim. In: Gupta B, editor. Higher plants of the Indian sub-continent. New Delhi: BSMPS; 1994. p. 164-6.

116. Charnley S, Fischer AP, Jones ET. Integrating traditional and local ecological knowledge into forest biodiversity conservation in the Pacific Northwest. Forest Ecol Mang. 2007; doi:10.1016/j.foreco.2007.03.047.

117. Bourdet-Sabatier S, Balikci-Denjongpa A. The Dzumsa of Lachen: an example of a Sikkimese political institution. Bull Tibetol. 2004; http://www. thlib.org/static/reprints/bot/bot_2004_01_04.pdf.

Submit your next manuscript to BioMed Central and we will help you at every step:

- We accept pre-submission inquiries

- Our selector tool helps you to find the most relevant journal

- We provide round the clock customer support

- Convenient online submission

- Thorough peer review

- Inclusion in PubMed and all major indexing services

- Maximum visibility for your research

Submit your manuscript at www.biomedcentral.com/submit
Biomed Central 